\title{
Biography and the Rehabilitation of the Subject: The Case of John Gorton
}

\section{Ian Hancock}

When I was an undergraduate, some years ago, I read a comment on biography by Sir Lewis Namier, the magisterial historian of eighteenth century British politics. Namier thought that someone embarking on a biography was no better qualified for the task than a woman who applied for the position of minding children and said in support of her application that she herself had once been a child. No doubt with the advancement of so many academic disciplines and the multi-skilling of so many academics, Namier's dismissal of biography is now out of date for most biographers. But not so in my case. When, therefore, I was commissioned to write a biography of Sir John Gorton (2002), a chapter on Sir Robert Askin (2006) and a long entry on Harold Holt in the Australian Dictionary of Biography (1996), I realised that my immediate problem was myself. Very simply, my qualifications, let alone my experience, did not equip me for the task.

Yet historians are always writing about events, people and context removed from their area of familiarity. So it did not really matter that, unlike Gorton and Askin, I was born of parents married to each other, or that, unlike the private schools Gorton and Holt attended in Victoria, mine had begun to curb the excesses of muscular Christianity if not of gender isolation. It did not matter that, unlike Holt's father, mine did not sabotage my self-esteem by seducing and then marrying the girlfriend I brought home to meet him. I did feel, however, that my stint as a staff sergeant in the school cadets, and firing a First World War rifle on field days, together with a general lack of intestinal fortitude, did not really prepare me to write about John Gorton. After all, he was a wartime fighter pilot, who barely survived two horrendous crash landings, whose ship was torpedoed after leaving Singapore, and who spent days on a raft waiting for a Japanese submarine to finish him off.

Nor did my time as the Communist Party Prime Minister of my school's Parliamentary Society actually assist my understanding of the political process. Even then, I suppose I did learn something about branch stacking, having used fellow boarders to get myself elected, and I also learnt, when later observing the federal Parliament, that juvenile behaviour can continue beyond adolescence. Moreover, my brief stints as a Liberal Party branch member, which always ended when I could invent a point of principle upon which to resign - that is, to escape - did at least alert us to the tedium and triviality and occasional manic absurdities of grass roots Liberal politics. 
Despite my doubts, I decided that after all those years of studying political history in Africa and Australia, and observing and sometimes dining at what Manning Clark called the 'Banquet of Life', I could give it a go. So, despite decades of theoretical under-nourishment, and feeling quite healthy nonetheless, I sallied forth remembering the tale of Hilaire Belloc's water beetle - best just to swim, for to stop and think, would be to sink.

That said, in writing the biography of John Gorton, Prime Minister of Australia between 1968 and 1971, I was troubled by two serious problems. First, I was officially a member of Gorton's staff. And, unlike many other biographers, I did not choose to write about my subject. In my case the subject chose me. I was paid a salary and expenses (which rewarded me well above the average royalty returns). Clearly, I risked being dismissed as a mere hireling employed to write a hagiography. Interestingly, no reviewers condemned me on that account, though some thought I could have been more critical.

James Walter has already flagged what became my second problem, though I do not much care for the term 'stakeholder', if only because universities have been demeaned and self-demeaned for too long by such usage. I had a research assistant - a particular research assistant whose name will be familiar to many - Ainsley Gotto. She was Gorton's one-time principal private secretary or chief of staff, who was appointed when she was just 22 years of age. She was also, for the purposes of the Department of Finance, my supervisor. In addition, she kept a watching brief on Gorton's behalf and, in the process of what diplomats would call a free and frank exchange, but I like to think of as a sparkling friendship, I learnt much about why Gorton chose her to administer his office and why and how she caused him considerable grief. The important point is that Ainsley probably wanted, and the second Lady Gorton most certainly wanted, was not so much a biography as rehabilitation.

Although I started out thinking that Gorton was not even a good prime minister, I came to agree that rehabilitation was more than justified. The unelected and unelectable members of the fourth estate, who had dismissed him as 'Bungles' and 'Jolly John,' had successfully cemented a number of conventional wisdoms which do not survive even a cursory examination of the voluminous official and personal records at the time, let alone a host of interviews. Yes, he did, on his own admission, drink too much. Yes, he broke what we Anglicans would think of as the Seventh Commandment (and he did so while he was prime minister). But was he lazy and none too bright? The marginal comments on Cabinet submissions alone should dispel both pieces of nonsense. He had more time on his hands than Harold Holt because of his instant grasp of the heart of any matter. And he was certainly sharper than Billy McMahon who underlined pretty well everything just in case he missed something important. For a bloke who claimed he majored in rowing whilst at Oxford, but put together a top upper-second 
when he could spare the time, John Gorton was probably one of the brightest minds ever to inhabit the Lodge.

Rehabilitation was no problem in another respect. The experts told me that Gorton was the best Navy Minister of the twenty-one Australia has so far had, the only rider being that the competition was not exactly fierce. More importantly, it was Gorton, initially under Menzies and then on his own, who piloted the Commonwealth's entry into primary and secondary education (to the enormous advantage of poorer Catholic schools), and who promoted the growth of the colleges of advanced education. As Prime Minister, Gough Whitlam sent a private note to Gorton - 'I intend to finish some of the things you started'.

The problem I faced was this. While I was happy to restore the public face and, indeed, to show it in what that great sage Mungo McCallum called 'tedious detail', I wanted to explain something which began to bother me when I finished telling the story. Why did this man not become an outstanding prime minister? He was, after all, more talented than most of our political leaders, and had a gift for touching what are sometimes called 'ordinary Australians', surpassed only by Bob Hawke in modern times. Some of the answers to my question could be found in the Menzies-led Liberal Party of the 1950s and 1960s. But I soon realised that important answers lay within Gorton himself. I was then reminded of Namier's dismissive remark. I was suddenly alone, naked and without qualifications.

Whether his illegitimacy played upon his mind (as some who do not know him well would have us believe), it probably did not require taking 'Psych 1 ' to recognise that Gorton's early life, where he was constantly being farmed out and denied affection, taught him to fend for himself, to do it his way. He would always be John Gorton, the fighter pilot, alone in the air, who wanted to be, and had to be, his own man. This was the John Gorton, the committed Australian nationalist and centralist who had, I believe, the right idea of taking on States' rights, but who as an outsider within the Liberal Party, never understood the need to coax and to compromise or even knew how to do so. Some of the stakeholders preferred this story, and wanted the story of his personal relationships to be glossed over. The saving grace was always Gorton himself: he could not care less, and told me to get on with it.

It was not just his childhood which moulded the man. Consider his last year at Geelong Grammar. It was 1930, the first full year of the Great Depression. James Darling, the new self-styled Christian socialist headmaster, arranged for the senior boys to deliver food parcels to the homes of the unemployed in Geelong. Decades later, Gorton was still speaking about the impact of seeing people battered by circumstances beyond their control, and of witnessing resentment in the eyes of broken men who had faithfully served their country in the Great War. I believe a line can be drawn between that experience and the Gorton who 
irritated the conservatives in his own party by thinking that social reform was more important than the forward defence of Australia.

And then there was Gorton's own war. Like so many of his contemporaries, he returned to Australia, in his case with his face disfigured by injuries, determined to transmit the values of war time service to the task of post-war reconstruction. As John Gorton himself put it: they wanted to build on the political freedom won on the battlefield, to make a better and more secure world for all Australians. That freedom, he believed, was threatened by the Chifley Labor government's decision in 1947 to introduce bank nationalisation. So, as a struggling orchardist and shire councillor from northern Victoria, he joined the anti-socialist crusade which bought many ex-servicemen to Canberra in 1949. By chance and without adequate training, he had the opportunity twenty-one years later to address those things which had so moved him in the 1930s and 1940s.

In March 1971 half of his colleagues voted against him in a 'no-confidence' motion in the party room. He gave a casting vote against himself - he did not know the rules, he did not have to, as no-one else did either. The wife of one of his colleagues would later say: 'Australia was ready for John Gorton, but the Liberal Party was not'. Determined, as always, to do it his way, he had not bothered to take his party with him. Excited in 1968 to get the job, he threw it away in 1971 because he was sick of the intriguers his lone hand had helped to foster, and who had become exasperated with his maverick leadership.

I could, as a biographer, rehabilitate him as a reformer and an idealist but, in trying to explain his downfall, I had to probe all of Gorton's complexity - to the annoyance of some of the stakeholders. There were, fortunately, many relieving moments. One of them involved investigating the fist fight which took place in Parliament House during a Senate dinner break. Gorton came to blows with Don Willesee, a Labor Senator from Western Australia. The seven men I interviewed, including the two participants, could not agree on where exactly in the building the incident occurred, when it occurred, why it occurred, or who won. Triangulation was impossible. 